\title{
The Effectiveness of the Quantum Method on Student Ability in Making a Creative Book
}

\author{
Sukirno \\ \{sukirnopwt56@gmail.com $\}$ \\ Faculty of Teacher Training and Education, Universitas Muhammadiyah Purwokerto
}

\begin{abstract}
The aim of the study is to find out (1) the application of the quantum method in learning to write creative books in universities, (2) the form of creative books written by students after obtaining creative writing lessons using the quantum method, (3) the number of titles in each creative book that students make, (4) the ability of students to develop their respective creative book building elements, (5) the ability of students to develop the structure of their respective creative books, (6) impressions when writing creative books, and (7) the obstacles experienced by students in writing the creative book. The quantum method is very appropriate to use for learning to write. With three parameters, this method can produce 90 titles of creative books by PBSI students. The three parameters of the process are context, content, and grafting steps. Context is applied in language that can suggest students, uses multi-media, and varies classroom management. The content is adjusted to the essential competencies and achievement indicators. The TANDUR steps are: Cultivate students' understanding and interest, Experience, Name, Demonstrate, Repeat, and Celebrate. Of the 90 titles of creative books by students, they consist of 63 titles of poetry anthologies, 16 titles of short stories collections, four titles of collections of personal experiences, three titles novels, one identification of a group of fairy tales, 1 title of a bookmaking shadow puppet, 1 title of a face painting book, and 1 title of a collection of love letters. In one semester, every student who writes an anthology of poetry, if on average, can register between 51-60 titles of poetry. On average, he writes short stories such as there are five titles, the average person experience is 15 titles, the average novel is 12 stories, 51 love letters, ten fairy tales, four chapters of shadow puppets, and face painting there are six chapters. Overall, students have been able to develop creative works based on their building elements. Students can structure the book well. By the quantum method, $25 \%$ of students are imaginative in writing creative books, $22 \%$ of students are more creative, $16 \%$ of students like to pourput ideas into written form, $16 \%$ of students have a sense of pride, $4.4 \%$ of students can increase their income. Constraints felt by $25 \%$ of students find it difficult to develop ideas that are stopped in the middle of the road, $22 \%$ of students find it difficult to relate the theme and flow of content, $16 \%$ of students do not understand how to make a good book, and $16 \%$ of students often deviate from the article.
\end{abstract}

Keywords: the effectiveness of the quantum method, the ability of students to make creative books

\section{Introduction}

One of the efforts to improve the quality of writing learning in universities is to improve the writing learning process by developing science and technology that has entered the era of the industrial revolution 4.0. To fulfill this, it is necessary to have a method that can create a 
fast, interesting/fun, and democratic learning system. The Ministry of National Education (2003:10) has formulated the basic principles of teaching and learning activities: developing logical, critical, creative thinking skills, attitudes, and being responsible for daily habits and behavior through active learning activities.

The main problems of this research are (1) how the application of the quantum method in learning to write creative books in universities is? (2) what kinds of creative books are written by students after learning to write creatively using the quantum method? (3) how many titles in each creative book do students make? (4) how is the student's ability to develop the elements of each creative book builder? (5) how are the students' abilities in developing the structure of their respective creative books? (6) what are the impressions when writing a creative book? And (7) what are the obstacles faced by students in writing the creative book?

\section{Learning with Quantum Method}

The term quantum is taken from quantum learning or accelerated learning (dePorter and Hernacki, 2003: 14), accelerated learning or learning quickly (Rose and Nicholl, 2003: 8), and know anything speedily or how to learn quickly (Linksman, 2004). Another term closely related to the quantum method is suggestology or suggestopedia (dePorter and Hernacki, 2003: 14). Suggestion means giving an impression, prompting, opinion, recommendation, advice, or request that comes up for consideration (Echols and Shadily, 1992: 567). In addition, a proposal also means encouragement or influence that can move people's hearts (Depdikbud, 1996: 969). Lozanov, a Bulgarian educator, has conducted experimental research with the suggestology learning model. In conclusion, it is said that suggestion has proven effective in schools and for all types of people of all ages. Proposals can and do affect learning situations and outcomes.

The basis for the development of the quantum method is the opinion of Rose and Nicholl (2003: 125), who explain right that obtaining information quickly, it can be done through various methods visual, auditory, and kinesthetic learning. Linksman (2004: xii) also says that every human people have a speed of learning with different learning styles, such as visual, auditory, notile, and kinesthetic.

In another section, it is explained that learning according to the modern approach is learning that is not only concerned with results, but also processes (Nunan, 1991: 86; Cleary and Michael, 1994: 346; Tompkins, 1994: 7). With the process approach, students are not only dependent on the role of the teacher, but more than that, students are responsible for their learning outcomes. With a process approach, the teacher plays a role in creating a safe and comfortable atmosphere. The class atmosphere in question is physical and intellectual (Temple, Ruth, and Nancy, 1988: 215). In this atmosphere, students may make mistakes without feeling afraid, and students think helped by the teacher to achieve goals. As Tompkins (1990:8) puts it, the failure of the student learning experience is often caused by the teacher's belief that students are unable to learn and there is no enthusiasm for the teacher to help students in carrying out learning activities.

Another modern view of learning is a social activity (Temple et al., 1988: 211; Nunan, 1991: 87; Cox and Zarrillo, 1993: 211). This shows that students can work together with 
others in the learning process so that language learning activities will look more realistic. Halliday also said by Halliday (in Cox and Zarrillo, 1993: 211) that children are part of a social community, and children build meaning in a social context.

Based on some of the opinions above, it can be said that the notion of quantum is accelerated learning or fast learning by giving encouragement that can move the hearts of students by utilizing the ability of their respective senses in improving the process and learning outcomes repeatedly and collaboratively.

\section{Parameters of Learning with Quantum Method}

Three main things that can be used as parameters for implementing the quantum method are context, content, and learning steps (Sukirno, 2010: 64). Context has three forms, that is language, media, and learning environment. The language referred to here is languages used by the teacher is expected to arouse students' enthusiasm for learning Indonesian language activities. dePorter et al. (2002: 17) explains how to create an exciting atmosphere, that is (i) the teacher must use language that can develop generate learning intentions, (ii) the teacher's language must be able to create a fabric of sympathy and mutual understanding, (iii) the teacher's language can create a cheerful and fantastic atmosphere, (iv) the teacher's language can create a sense of belonging, and (v) teacher behavior can be used as an example for students. All of this is realized by using language that is easy to understand, objective, active, intellectual, friendly, engaging, full of humor, and many words are suggestive.

The media used in this learning is media that can help facilitate the learning process. Three media can be used, that is viewing media, listening media, and listening-view media. Three media are used to help students with different learning styles. The learning environment created through the quantum method is a learning environment that is safe, comfortable, supports the learning process, is relaxed, and has exhilarating. To realize such an environment, two environments must be created, that is physical and atmosphere. The physical environment is created by utilizing physical activity for learning in limb movements, making changes to the appropriate learning place, learning by using various games and competitions. The atmosphere environment creates a comfortable atmosphere, sufficient lighting, the availability of adequate learning media in which there are elements of moving images, dialogue, music, events, and pleasing to the eye.

Learning content creative writing is learning material learning by the essential competencies in the curriculum. Content parameters are embodied in lesson plans and assessment systems other. The lesson plan contains core competencies, critical competencies, achievement indicators, learning objectives, subject matter, learning steps, learning methods, learning media and resources used, and assessment techniques. Learning resources come from lecturers, relevant books, various print, and electronic media, and sources from internet media.

Learning steps Creative writing with the quantum method uses six main steps known as tandur: growing, experience, name, demonstrate, repeat, and celebrate (Sukirno, 2016: 22). To grow is to develop students' understanding and interest in teaching materials by suggesting and explaining the schemata of teaching materials to students. Experience is that students immediately explore choosing the materials and learning styles they like. The name is 
discussing the results of the identification of learning material elements in group discussions. Demonstrations are students realizing learning activities as the core of learning material in language skills actions. Repeat is to improve student learning outcomes based on suggestions from friends and lecturers to become more perfect. Celebrate is the activity of students and lecturers in determining the assessment of student work through theoretical and practical exams.

Based on the description above, it can be concluded that learning with the quantum method referred to here is the process of accelerating and optimizing student learning outcomes based on sensory abilities and working together by utilizing the use of motivational language and appropriate media and learning resources to create a comfortable learning situation for the achievement of competence with and steps.

\section{Creative Book Writing}

The term creative means (1) having the power to create or having the ability to create; (2) is (contains) creative power. Creativity means creative things. Creator means creator or originator of ideas. Creativity means the ability to create (Depdikbud: 1996: 530). So, writing a creative book is an activity of expressing ideas in writing or through writing generate creativity based on thoughts and feelings in the form of writing or essays in the form of books. Examples of creative books are essay books, collections of personal experiences, autobiographies, biographies, travel stories, collections of short stories, novels, collections of legends, collections of fairy tales, collections of drama scripts, film scenarios, poetry anthologies, collections of letters, groups of opinions, speeches, books how to paint, books on how to use used goods, how to make shadow puppets, and others. Learning to write creative books is a learning process that can realize the activities of students to produce their creative books.

Creative books can be sold freely. There are also creative books that include types of monumental works that can be performed locally, nationally, or internationally, such as drama scripts, fairy tales, film screenplays, poems, and legends. Creative books can be used in schools and colleges to support teaching programs (Buckingham, 1958:1523).

\section{Creative Book Structure}

This creative book is developed into three groups: preliminary group, leading group, and complementary group. The initial group consists of a cover, preface, and table of contents. The body contains five elements, that is (a) paper size and quality, (b) writing, (c) illustrations/pictures, (d) color, and (e) meaning. Paper size and quality, as well as binding, need attention. Some of the writings on the cover of a creative book include the author's name, the title of the book, the name of the institution in charge or publisher, the person in charge/publisher, and the year of publication. The colorful and meaningful illustrations/images that clarify the material's content will increase the book's readers.

The preface at least contains an introduction to the background of the book being made, explaining the contents of the book as a whole, thank all those who helped make the book happen, the author's hopes for the readers, gratitude, and the place of month and year of writing the book. The table of contents contains the names of the contents of the textbook along with the page numbers. The table of contents includes three parts: the preliminary 
section using lowercase Roman numerals, the central area using Arabic numerals, and the supplementary section using Arabic numerals. The table of contents as an outline of the book must pay attention to the balance of contents. If the text contains chapters, then the contents of chapter I, chapter II, chapter III, and so on must have balance.

The main section of the creative book contains areas of creative work. The parts of creative works are manifested in the form of titles. The titles are developed in the form of creative work content. Each title starts on a new page. It would be more interesting if in each title there were illustrations/pictures/photos that supported the content to suggest readers be more interested in reading the book.

The complementary part of the creative book contains at least two main things: photos and author biodata. The author's photo and biodata are included in the creative workbook so that his face is recognized and the detailed biodata of the author of the book is known. You can also add a bibliography, a glossary, and a short article on the back cover that contains the importance of reading a creative book.

\section{Building Elements of Literary Works}

Waluyo (2010: 27) explains that what builds poetry consists of inner and physical elements. The inner aspect of poetry, or often referred to as the essence of poetry, includes four things, that is theme, taste, tone, and mandate. The physical elements of poetry, sometimes also called the method of poetry, are used by poets to express the nature of poetry. The physical aspects of poetry include six things, that is appearance, diction, imagination, concrete words, figurative language, and diversification.

Sukirno (2016: 84) explains that the elements of a short story builder consist of actors, plot, setting, point of view, message, and story theme. The actors of the short story can be humans, animals, plants, and other objects personified like humans. Each actor has a character or personality that can distinguish the main actor and the auxiliary actor, the good actor and the bad actor. The main character or supporting actor can be known from his involvement in the story.

When viewed from the sequence of events, the story's plot consists of the beginning, middle, and end. More detail consists of exposition, conflict, climax, dissolution, and resolution. When viewed from the type, plots can be grouped into a forwarding or progressive schemes (events are told from the beginning, middle, and end), backward or regressive plans (described from the future, middle, only the beginning), combined, or back-and-forth plots. (events are sometimes told from the center, only to the beginning and end), and circular field (events are related from beginning to end. However, the ending goes back to the front). When viewed from the story ends, there are closed plots (the author has concluded or finished the story) and open plots (the author does not complete the end of the story, readers or listeners are welcome to complete the ending themselves).

The plot can be seen from the quality, that is, dense plot and loose plot. A thick action means that small stories cannot slip the event. Small parcels can tuck in the open property. There are two types of fields based on quantity: single plots (telling only one episode of life) and double plots (describing more than one episode of life). By its short and dense nature, short stories do not have loose plots and double plots.

Setting the story consists of setting the place, setting of time, and setting the situation. The site's setting can be the name of the country, province, district/city, vast open nature, the 
name of the building, ample space, and a narrower margin. The time setting can show time, morning, afternoon, evening, night, day, week, month, year, and time. The setting of the situation is telling the case of rain, light, busy, calm, angry, safe, chaotic, sad, happy, alone, many people, and other situations.

Point of View is the position of the author in the story he writes. The point of view consists of the first person point of view (accompaniment). In this case, the author is the main actor. As for the second-person point of view (included acknowledgment), the author's position is involved in the story, but not as the main actor. In the third-person point of view (he is omniscient and limited), the author is not engaged in the story. The author is only a narrator. If the author knows all the events in the novel, such a position includes the omniscient third person. On the other hand, if the author does not know everything that happened, including the third person, it is limited.

The theme is the meaning of the story, the central idea, or the basis of the story to be fought for in the story. The article serves to serve the author's total attention to experience and its relationship to the environment at hand. Themes have several types: physical themes, moral themes, social themes, egoistic themes, and religious themes. The five pieces can be further broken down into sub-themes with a narrower scope than the central theme.

Message the short story is the moral message of the author of the short story that the author wants to convey to his readers so that at the end of the story, the reader can learn the wisdom behind the incident. Therefore, the message is simple and easy for readers to grasp.

Transition words are the use of words or phrases that connect one idea to another, whether contained between one clause and another in a sentence, one sentence with another sentence contained in a paragraph. Transition words are also used to connect one section to the next. Transition words can refer to actors, times, places, and situations.

Examples of transition words that designate actors: they, they, we, I, we. Example of transitions form indicate time: meanwhile, then, next, soon. Examples of transitions designate places: there, in between, above, in, next to. Examples of transitions that indicate situations: calm, quiet, noisy, happy, sad, raining, light, dark. Examples of transitions denoting something have been mentioned before: besides, next, then, in the meantime, in addition, besides, so. Examples of transitions show effect: therefore, consequently, thus. The example of change points to the opposite of what has already been mentioned: however, on the contrary, otherwise.

\section{Research Methods}

This research is a classroom action research with quantum method parameters. The subjects of this study were the sixth-semester students of PBSI, FKIP, Purworejo Muhammadiyah University, as many as 90 students. The research time is for one semester from February to July 2019. The research location is at the Indonesian Language and Literature Education Study Program, Faculty of Teacher Training and Education, the University of Muhammadiyah Purworejo for the 2018/2019 academic year. The object of this research is the ability of students to make creative books. This research focuses on the number and types of creative books created by students, the number of essay titles in each creative book, the development of the building blocks of the content of each creative book, the 
development of the structure of the innovative book form, impressions, and problems when students write books. The assignment technique is to determine the ability of students to make the type of book, the development of the number of titles in the book, the story of content building elements, and the structure of the booking form, are the questionnaire technique was used to find out the impressions and obstacles experienced by students when making creative books. The instrument used in this research is the human instrument (researcher as the main instrument) assisted by a data recording card. Data analysis techniques used are structural analysis and content analysis (Bungin, 2015: 163). The presentation of the study results used informal techniques (analysis with ordinary words without using signs and symbols) (Sudaryanto, 2015: 241).

\section{$3 \quad$ Results And Discussion}

Before presenting the results of the data analysis, it was explained that from the beginning of the lecture, students had been informed that at the end of this lecture, students were required to make one creative book title. During one semester, students learn creative writing using the quantum method. The material presented is 12 chapters. Chapter I discusses the nature of learning to write creatively, chapter II on the nature of quantum-based learning, chapter III on the characteristics of quantum learning, chapter IV writing personal experiences, chapter V writing biographies, chapter VI writing short stories, chapter VII writing legends, chapter VIII writing fairy tales, chapter IX wrote the drama script, chapter X wrote the screenplay, chapter XI wrote the opinion, and chapter XII wrote the poem. Each chapter is presented in the learning process with the quantum method.

The main objectives of learning to write creatively with the quantum method are twofold, that is (1) to introduce students to how to learn to write creatively with the quantum method and (2) to give examples and at the same time open the knots of ideas that are in the minds of students to be appointed as the topic of creative books. It is hoped that the opening of the inducement of ideas will motivate students to develop their ideas in their creative books.

At the end of the lecture, students are assigned to make creative books according to their individual choices. In addition, students were also asked to write down the impressions and obstacles they experienced when writing the innovative book. The results of this study are described in detail in the description below.

\subsection{Creative Books Written by Students After Getting Learning to Write Creative with Quantum Method}

Based on the results of data analysis, it is known that from 90 students, 63 students make poetry anthology books, a collection of short stories as many as 16 students, a group of personal experiences by four students, novels by three students, fairy tales by one student, shadow puppets by one student, face painting by one student, and a collection of love letters by one student. The data was obtained from Class VI A, who wrote a collection of poetry as many as 22 students, a group of short stories by four students, a collection of personal experiences of 2 students, and the skills of making shadow puppets by one student. Class VI B produced 16 poetry anthologies, ten short stories anthologies, one novel, one fairy tale, and 
one face painting title. Class VI C made eight collections of poetry, two books, and two collections of short stories. Class VI D produced 14 collections of poetry, two personal experiences, and one collection of short stories.

The size of the book is almost the same, that is half a folio with a length of $21 \mathrm{~cm}$, a width of $15 \mathrm{~cm}$. The difference lies in the thickness of the book and the number of pages. The thinnest is 52 pages, while the thickest is 218 pages. All books are neatly bound, and books are marketed using white HVS paper and paper head as the book's cover. The color of the book cover is various. There are blue, yellow, black, red, green, brown, purple, and variations/mixes.

\subsection{Number of Titles in Each Student's Creative Work Book}

The researchers describe the number of titles in each group of types of books as follows. Books A collection of 63 poetry titles. Poetry anthologies are among the most liked by students, of the sixty-three collections of poems that contain at least 33 poetry titles, the most holding 108 poetry titles. Two students wrote poetry between 33-40 tags, 20 students wrote poetry between 41-50 titles. Twenty-one students write poetry between 51-60 titles. Nine students wrote poetry between 61-70 titles. Three students write between 71-80 poetry titles. There is no poetry writing between $81-90$ tags and seven students who write poetry between 91-108 titles. Based on these figures, it can be said that the average student can register between 51-60 tags of poetry in one semester.

Furthermore, 16 students wrote short stories anthologies. Of the 16 students who wrote the most straightforward stories, one student wrote 13 short stories. There are at least five students who write short stories, that is, five short stories each. Hierarchically, there was one student who wrote 13 short stories. Six students wrote ten short stories. Those who wrote nine short stories were two students, two students wrote eight short stories, and five students wrote five short stories. So the average ability of students to write short stories is five titles in one semester.

Of the 16 short stories, one pack contains ten short stories, and the ten short stories have been selected as the best short stories at the district, provincial and national levels. The collection of short stories is entitled Ruang Kontemplasi, written by Putu Aspira Suite.

Four students wrote personal experiences. Of the four students who wrote 20 titles of personal experience, one student wrote 16 titles of personal experience, one student wrote 14 titles of personal experience, and one student wrote 12 titles of personal experience. From these data, it can be said that the average student's ability in writing personal experiences is 15 titles in one semester.

Three students write novels. The first novel is entitled Sang Pemilik Hatiku. The second novel is entitled Istiqoroh Cinta Faizah. The third novel is entitled Pelangi Tanpa Warna. The first novel contains 15 story titles, the second novel has 14 story titles, while the third novel contains eight-story titles. From these data, it can be seen that in one semester, three students can make three novels with an average of 12 story titles.

The motivation for learning to write creatively with the quantum method can give birth to four other exciting writing titles, that is one collection of love letters, one slip of a group of 
fairy tales, one marker of skill in making shadow puppets, and a title of tips for commercializing face painting. A collection of love letters entitled Untukmu Lelaki Bayangan contains 50 love letter titles. A group of fairy tales entitled Dewa Guntur dan 9 Dongeng Lainnya has 10 fairy tales. Furthermore, the book entitled Keterampilan Membuat Wayang Kulit includes four chapters. The book entitled Kiat Mengomersialkan Melukis Wajah contains six chapters. It's not an easy job to write a creative book. However, with a touch of the quantum method, 90 students could motivate to do creative works.

\subsection{Student's Ability in Developing Elements of Creative Works}

The ability of students to develop elements of creative work can be seen from the types of books made by each student. The following describes the building blocks based on the kinds of innovative books that students write.

The poetry anthology, which consists of 63 books, has been built on two elements: the mental and physical elements. The inner aspect of poetry includes four things: the theme/meaning, feeling/attitude of the poet towards the problems faced, the tone/mood of the poet towards his readers, and the message/ poet's message. The physical elements of poetry made by students include six things, that is appearance/typography, diction/word choice, imagination/imagining power, concrete words, figurative language, and diversification/ acceptance.

Almost all students can create poetry by paying attention to the poem's structure, such as the title of the poem, the name of the author, the verses of the poem, the lines of the poem, where and when the poem was created. In addition, students are also able to create poetry by using the two building elements mentioned above. However, the sharpness still needs to be improved in spiritual and physical characteristics. The inner element is sharpened through the physical feature related to only typography, diction, imagination, concrete words, figurative language, and rhymes. To achieve a high literary weight, there needs to be inner sensitivity and breadth of insight, and mastery of the creator's vocabulary. This can be achieved if it is done continuously by the author create. From the aspect of structure, there are still some poetry anthologies that need to be perfected.

Sixteen short anthologies written by students have been developed with a complete short story structure: the title of the short story, the name of the author of the short story, the content of the short story, and at the end where and when the short story was written. In addition, students have also developed entirely harsh story-building elements: characters and characterizations, setting, plot, theme, point of view, and message. Each short story title has raised the name of a character, and there is a place where the events occur, there is a sequence of events, a theme/main idea, a point of view, and the message. However, that does not mean that the short stories do not have weaknesses. There are still many things that need to be strengthened to obtain a short story with more literary weight.

Things that still need to be improved include the clarity of the characters and their depiction, the clarity of the background of the events, the clarity of the plot of the circumstances, the clarity of the point of view, and the clarity of the message. From the linguistic aspect, it is necessary to improve diction, depth of content, sentence structure accuracy, and spelling.

The four students who wrote personal experiences have also developed their building blocks well. Because it is unique, personal experience writing has the characteristics of a free form and method of writing. As found in the diary, telling stories the events that occur, the time, and the place where the events occur, the contents are individual or selfish, subjective, 
the language is natural, ordinary, natural, simple, frank, lively, charming, refreshing, vibrant, and served live. At least, the elements of the perpetrator's name, the events that occurred, the place and time of the incident are always in it.

What still needs to be improved is the selection of diction, sentence structure, and improved spelling. Students still do not use a broad vocabulary, so they are fixated on words or terms that are repeated and less varied. The sentence structure is still found to be ineffective. The use of spelling such as capital letters and punctuation is still found not to be correct.

Of the three titles of novels written by students, in general, students have been able to develop the elements of novel building well. The main aspects of the story, additional actors, characters, depiction of characters, setting of the place, setting of time, setting of situation, cultural background, plot development, point of view, message, and themes can all be enjoyed. The development of the plot according to the sequence of events, according to its type, according to the way the story ends, seen from the quality and quantity, has also been partially found.

The drawback is that it still needs to be improved from the clarity of each of these elements so that the novel text is more complete, precise, in-depth, and has literary weight. The clarity and sharpness of the development of each of these building elements are known from the linguistic aspect. Therefore, proper diction, appropriate transition words, correct sentence structure, use of proper spelling, and correct punctuation are essential. No matter how good the content or meaning in the novel is, without being presented with appropriate and adequate language, the goodness of the novel's contents cannot be enjoyed. Therefore, the linguistic aspect is essential and determines the integrity of the story.

The development of the building elements of a fairy tale entitled Dewa Guntur dan 9 Dongeng Lainnya includes aspects of character and characterization, setting, plot, point of view, and values. The characters in the story are humans (father, mother, children, neighbors), animals, and spirits. Each character can be seen in the description of nature. Some are good, and some are bad. The setting is inside the house, outside the house, in the village, in oil palm plantations, in the forest, and the vast nature. The time setting is morning, afternoon, evening, and night. The background of the situation depicts a simple life, poor, rich, rainy, bright, lonely, and thunderous. I am judging from the type most of the forward grooved. Judging from the way the story ends with a closed plot, judging from the quality, it includes a solid field. By its nature, the fairy tale has an omniscient third-person point of view. The values that can be learned from these fairy tales are generally the value of moral education that targets the listener to have good morals.

Next up is the book called Keterampilan Membuat Wayang Kulit. This book was written by a student who happens to be a puppeteer named Danang Afriana. The book was developed starting from the title, catalog, foreword, table of contents, chapter I introduction, chapter II puppet characters and their characteristics, chapter III preparation of tools and materials, chapter IV making shadow puppets, bibliography, glossary, and author's biodata.

The next book is entitled Kiat Mengomersialkan Melukis Wajah. This book was written by a student who also happens to be an artist, especially in painting. His name is Chairul Ikhwan. This book was developed starting from the title, catalog, foreword, table of contents, chapter 1 introduction, chapter 2 painting tools, chapter 3 basic painting techniques, chapter 4 painting the face of the eyes, nose, and mouth, chapter 5 painting the ear face, hair, 
improvements to face painting and caricature painting, chapter 6 drawing Japanese anime/cotton and drawing doodle art quickly, chapter 7 some suggestions and tips, glossary, bibliography, and author's bio.

The last is a collection of love letters entitled Untukmu Lelaki Bayangan. This book was written by a student named Selviani, whose pen name is Woman Lovers of Love. Incredibly, she can write 50 exciting love letter titles. As the title suggests, the theme of this collection of love letters is the romance between a man named Shadow Man and a woman named Love Lover. Judging from the time of writing, this type of love letter flow is forward. Letters were written from September 6, 2017, to June 10, 2018. When viewed from the order of contents, one note to another is not always sequential, meaning that the contents of the following letter are not necessarily a continuation of the previous letter. However, the outpouring of a woman's heart who loves love is always addressed to the Shadow Man.

\subsection{Student Ability in Developing Creative Book Structure}

In general, students can develop the structure of their creative books well. Each book already has a book cover that includes the title of the book, the author's name, equipped with pictures/photos/illustrations, and the color of the body that reflects the contents of the book. It is also equipped with a preface, table of contents, contents of the book, and author's bio. Readers of a scientific nature are added to the bibliography and glossary. The complete structure of student workbooks can be seen in Table 1 below.

Table 1. Student's Creative Book Structure Development.

\begin{tabular}{clcc}
\hline No & \multicolumn{1}{c}{ Book Structure } & Amount & Percentage \\
\hline 1 & $\begin{array}{l}\text { The cover of the book contains the title, author's } \\
\text { name, pictures/illustrations/ photos that match the }\end{array}$ & 90 & $100 \%$ \\
& & \\
& contents & 5 & $5.5 \%$ \\
2 & Offerings to people who are respected/loved & 10 & $11 \%$ \\
3 & Preface/short comments from readers/friends of & & \\
& the author & 88 & $98 \%$ \\
4 & Foreword from the author & 88 & $98 \%$ \\
5 & Table of contents and pages & 88 & $98 \%$ \\
6 & Fill in the book according to the table of contents & 90 & $100 \%$ \\
7 & Every post title starts from a new page & 80 & $89 \%$ \\
8 & Each tag has the name of the creator & 80 & $89 \%$ \\
9 & At the end of the work is written where and when & & \\
& it was written & 80 & $89 \%$ \\
10 & Standard fonts and font sizes & 75 & $83 \%$ \\
11 & Standard spacing size & 90 & $100 \%$ \\
12 & White paper base color & 90 & $100 \%$ \\
13 & Writing typography & 75 & $83 \%$ \\
14 & Compliance with EYD kaidah rules & 85 & $94 \%$ \\
15 & In the end, the author's complete biodata is loaded & & \\
& along with his photo & 2 & $2.2 \%$ \\
16 & Bibliography & 2 & $2.2 \%$ \\
17 & Glossary & 85 & $94 \%$ \\
18 & The back cover is filled with pictures and text that & & \\
\hline
\end{tabular}




\subsection{Student Impressions in Writing Creative Books}

Based on a questionnaire filled out by 90 students who wrote various creative works, it is known that students feel 37 impressions in writing creative books. Of these, each student has an average of four images. The overall impression can be seen in Table 2 below.

Table 2. Student Impressions in Writing Creative Books

\begin{tabular}{|c|c|c|c|}
\hline No & Book Structure & Amount & Percentage \\
\hline 1 & It can be a place of the outpouring & 9 & $10 \%$ \\
\hline 2 & $\begin{array}{l}\text { There are many benefits in pouring ideas into } \\
\text { written form }\end{array}$ & 15 & $16 \%$ \\
\hline 3 & Can recall the experience experienced & 8 & $8.8 \%$ \\
\hline 4 & Increase the power of imagination & 10 & $11 \%$ \\
\hline 5 & Increase knowledge & 8 & $8.8 \%$ \\
\hline 6 & Love & 9 & $10 \%$ \\
\hline 7 & Fun & 15 & $16 \%$ \\
\hline 8 & Add and train creativity & 10 & $11 \%$ \\
\hline 9 & Practice solving problems & 7 & $7.7 \%$ \\
\hline 10 & Like advising yourself & 6 & $6.6 \%$ \\
\hline 11 & Can provide benefits for readers & 7 & $7.7 \%$ \\
\hline 12 & It can make you smile reading your work & 6 & $6.6 \%$ \\
\hline 13 & Can express what is felt and thought & 8 & $8.8 \%$ \\
\hline 14 & $\begin{array}{l}\text { Sometimes I get carried away with emotions as } \\
\text { written }\end{array}$ & 5 & $5.5 \%$ \\
\hline 15 & Gaining experience in creative writing & 8 & $8.8 \%$ \\
\hline 16 & Become more confident & 10 & $11 \%$ \\
\hline 17 & $\begin{array}{l}\text { Can feel how the results of writing that are simple } \\
\text { but full of meaning }\end{array}$ & 5 & $5.5 \%$ \\
\hline 18 & $\begin{array}{l}\text { Can represent all feelings and increase the power } \\
\text { of imagination }\end{array}$ & 7 & $7.7 \%$ \\
\hline 19 & $\begin{array}{l}\text { It can pour out the heart/feelings and thoughts in } \\
\text { written form }\end{array}$ & 14 & $15 \%$ \\
\hline 20 & $\begin{array}{l}\text { Remembering the hard times and struggles that } \\
\text { have been done }\end{array}$ & 5 & $5.5 \%$ \\
\hline 21 & Appreciate the things that have been felt & 5 & $5.5 \%$ \\
\hline 22 & Can share stories with readers & 9 & $10 \%$ \\
\hline 23 & Increase self-satisfaction & 12 & $13 \%$ \\
\hline 24 & Cultivate a sense of pride in being able to work & 15 & $16 \%$ \\
\hline 25 & Train critical thinking & 9 & $10 \%$ \\
\hline 26 & Can increase income & 4 & $4.4 \%$ \\
\hline 27 & Be more creative & 20 & $22 \%$ \\
\hline 28 & Imagination increases & 14 & $14 \%$ \\
\hline 29 & Be diligent in using free time to write & 9 & $10 \%$ \\
\hline 30 & It becomes easier to solve problems & 12 & $13 \%$ \\
\hline 31 & Train students to imagine & 23 & $25 \%$ \\
\hline 32 & Appreciate the time to write & 13 & $14 \%$ \\
\hline 33 & Enrich vocabulary & 10 & $11 \%$ \\
\hline 34 & Enjoy literature & 14 & $14 \%$ \\
\hline 35 & More challenged & 13 & $14 \%$ \\
\hline 36 & Able to express ideas & 15 & $16 \%$ \\
\hline
\end{tabular}


37 Can express thoughts and feelings in writing $\quad 15 \quad 16 \%$

\subsection{Constraints Experienced by Students in Writing Creative Books}

Based on the questionnaires written by students, there are many obstacles experienced by students in writing creative books. This problem occurred because almost all students admitted that it was their first time writing a clever book. It can be known through their foreword or preface. To reduce these obstacles, it takes time to get used to writing books over and over again. Overall there are 36 types of barriers experienced by students, as shown in Table 3 below.

Table 3. Student Obstacles in Writing Creative Books

\begin{tabular}{|c|c|c|c|}
\hline No & Book Structure & Amount & Percentage \\
\hline 1 & It's hard to find inspiration & 9 & $10 \%$ \\
\hline 2 & It's hard to tell/tell back & 9 & $10 \%$ \\
\hline 3 & Frequently repeating words & 8 & $8.8 \%$ \\
\hline 4 & It's hard to determine the title & 10 & $11 \%$ \\
\hline 5 & It's hard to choose the right diction/word & 8 & $8.8 \%$ \\
\hline 6 & It's hard to define imagination & 9 & $10 \%$ \\
\hline 7 & Need peace & 15 & $16 \%$ \\
\hline 8 & It's hard to put words together & 10 & $11 \%$ \\
\hline 9 & Confused to determine/choose a title & 7 & $7.7 \%$ \\
\hline 10 & It's hard to design a book that looks interesting & 6 & $6.6 \%$ \\
\hline 11 & It takes patience and time to produce good work & 7 & $7.7 \%$ \\
\hline 12 & Stuck in ordinary words & 6 & $6.6 \%$ \\
\hline 13 & Lack of insight in choosing words & 8 & $8.8 \%$ \\
\hline 14 & It's hard to choose words that match the title & 5 & $5.5 \%$ \\
\hline 15 & Remembering to get a continuous writing & 8 & $8.8 \%$ \\
\hline 16 & Feeling awkward in choosing diction & 10 & $11 \%$ \\
\hline 17 & Imagination does not appear & 5 & $5.5 \%$ \\
\hline 18 & $\begin{array}{l}\text { Understanding of writing book covers is still } \\
\text { lacking }\end{array}$ & 7 & $7.7 \%$ \\
\hline 19 & Confused where to start the story & 14 & $15 \%$ \\
\hline 20 & In the middle of the story, the deck runs out & 5 & $5.5 \%$ \\
\hline 21 & Confused to make exciting sentences & 5 & $5.5 \%$ \\
\hline 22 & Difficulty analyzing story material & 9 & $10 \%$ \\
\hline 23 & Worrying about standard rules & 12 & $13 \%$ \\
\hline 24 & Often deviates from the theme & 15 & $16 \%$ \\
\hline 25 & Must read a lot & 9 & $10 \%$ \\
\hline 26 & Searching archives of past creative works & 4 & $4.4 \%$ \\
\hline 27 & $\begin{array}{l}\text { Difficulty connecting between themes and content } \\
\text { flow }\end{array}$ & 20 & $22 \%$ \\
\hline 28 & $\begin{array}{l}\text { Difficulty making a book cover that is attractive } \\
\text { and reflects the content }\end{array}$ & 14 & $14 \%$ \\
\hline 29 & Difficulty developing sub-themes & 9 & $10 \%$ \\
\hline 30 & Less creative & 12 & $13 \%$ \\
\hline 31 & $\begin{array}{l}\text { It's hard to develop ideas that get stuck in the } \\
\text { middle of the road }\end{array}$ & 23 & $25 \%$ \\
\hline 32 & It's hard to determine the title & 13 & $14 \%$ \\
\hline 33 & Lost ideas & 10 & $11 \%$ \\
\hline 34 & Indecisive in determining the storyline & 14 & $14 \%$ \\
\hline
\end{tabular}




\begin{tabular}{llll}
35 & Misplaced ideas that have appeared & 13 & $14 \%$ \\
36 & Lack of understanding in making a good book & 15 & $16 \%$ \\
\hline
\end{tabular}

\section{Conclusion}

Based on the explanation above, it can be concluded that after Semester VI, students of PBSI, FKIP Muhammadiyah University Purworejo received creative writing lessons using the quantum method for one semester. In general, they were able to write one creative book according to their individual choices. Every creative book he has written contains a good title for a book or anthology, has been developed based on its building blocks and has been compiled based on a good book structure. Several student works have also been published, and all student books are worthy of sale to the public. What needs to be improved is the use of language and the depth of the weight of the content. In addition, students get a positive impression that raises their enthusiasm and motivation to write books. However, many obstacles hinder him because, according to his admission, this job is the first time he has experienced it. Considering these conclusions, it can be said that learning to write creative books based on the quantum method has proven to be effective.

\section{References}

[1] Bungin, Burhan. Penelitian Kualitatif. Jakarta: Kencana Prenada Group. (2009).

[2] Cleary, L.M. and Michael, D.L. Linguistics for Teacher's. New York: McGrow-Hill, Inc. (1993).

[3] Cox, C. and Zarrillo, J. Teaching Reading with Children's Literature. New York: Macmillan Publishing Company. (1993).

[4] Depdiknas. Kurikulum 2004 Pedoman Umum Pengembangan Silabus Berbasis Kompetensi Sekolah Menengah Atas. Jakarta. (2003).

[5] Depdikbud. Kamus Besar Bahasa Indonesia. Edisi Kedua. Jakarta: Balai Pustaka. (1996).

[6] dePorter,B., Reardon, M., Naurie, S.S. Quantum Teaching: Mempraktikan Quantum Learning di Ruang Kelas. Translator, Ary Nilandari. Bandung: Kaifa. (2002).

[7] dePorter, B. dan Mike H. Quantum Learning. Translator, Alwiyah Abdurrahman. Bandung: Kaifa. (2003).

[8] Echals, J.M. dan Shadily, H. Kamus Indonesia- Inggris. Jakarta: PT Gramedia. (1992).

[9] Essex, C. "Teaching Creative Writing in the Elementary School. ERIC Digest. (1996). http:// www.ericfacility.net/databases/ERIC- Digests/ed391182.html.

[10] Hernowo. Quantum Writing. Bandung: MLC. (2003).

[11] Keh, C.L. 1990. "A Design for a Process-Aproach Writing Course.” Forum. Volume XXVIII Number I January. Page 10-12.

[12] Leonhardt, M. 99 Cara Menjadi Anak Anda Bergariah Menulis. Translator, Eva Y. Nukman. Bandung: Kaifa. (2001).

[13] Linksman, R. How to Learn Anything Quickly. New York: Barnes \& Noble Books. (2004).

[14] Novakovich, J. "Menulis Fiksi dan Nonfiksi" in Quantum Writing Cara Cepat nan Bermanfaat untuk Merangsang Munculnya Potensi Menulis. Translator and (ed.) Hernowo. Bandung: Kaifa. (2003).

[15] Nunan, D. Language Teaching Methodology. Sydney: National Centre for English Language Teaching an Research. (1991).

[16] Percy, B. The Power of Creative Writing. Englewood Cliffs: Prentice-Hall, Inc. (1981).

[17] Rose, C. dan Nicholl, M.J. Accelerated Learning For The $21^{\text {st }}$ Century. Translator,Dedy Ahimsa. Bandung: Nuansa. (2003).

[18] Sayuti, Suminto A. Berkenalan dengan Puisi. Yogyakarta: Gama Media. (2008). 
[19] Sudaryanto. Metode dan Aneka Teknik Analisis Bahasa. Yogyakarta: Universitas Sanata Dharma Anggota APPTI. (2015).

[20] Sukirno. 2003. "Sistem Ekologi dan Metafora Puisi Abacadabra Kita Ngumpet... Karya Emha Ainun Nadjib" Pinisi Jurnal Pendidikan Bahasa dan Seni Universitas Negeri Makasar. Vol. 08, No. 1, Desember (Page 1--11) ISSN: 0853-3563

[21] Sukirno. 2004. "Proses Kreatif Menulis dan Pembelajarannya di Sekolah." Surya Magazine Universitas Muhammadiyah Purworejo. No. 57 Tahun XVII Maret (Page 55-68) ISSN: 08529906

[22] Sukirno. 2006. "Pembelajaran Menulis Cerpen dengan Strategi Tandur." Surya Magazine Universitas Muhammadiyah Purworejo. No. 68 Tahun XIX Desember (Page 15-23) ISSN: 0852-9906

[23] Sukirno. 2008. "Pengembangan Model Perangkat Pembelajaran Bahasa Indonesia Berbasis Pendekatan Akselerasi Sebagai Upaya Peningkatan Mutu Pembelajaran Bahasa Indonesia." Prosiding Seminar Internasional Bahasa Indonesia/Malaysia dan Pembelajarannya. ISBN 978979-8587-60-3 (Page 281-296)

[24] Sukirno. 2009. "Model Perangkat Pembelajaran Menulis Biografi dengan Strategi Belajar Kuantum.” Jurnal Ilmu Pendidikan (JIP) (Accredited) Jilid 16, No. 1, Februari (Page 40--50). ISSN: 0215-9643

[25] Sukirno. Pembelajaran Menulis Kreatif dengan Strategi Belajar Akselerasi. Purworejo: UMP Press. (2009).

[26] Sukirno. "Pembelajaran Puisi dengan Strategi Belajar Kuantum" dalam Cara (Pengalaman) Saya Mengajarkan Sastra. Semarang: Bandungan Institute. (2009).

[27] Sukirno. 2010. "Pengembangan Model Perangkat Pembelajaran Menulis Legenda dengan Strategi Belajar Kuantum.” Kajian Linguistik dan Sastra (Accredited). Vol. 22, No. 1 Juni.

[28] Sukirno. 2010. "Modhel Pasinaon Bahasa Jawa sing Cepet Bisa lan Nyenengake". Paper presented at the International Conference on Regional Culture and Presentation of the "Rancage" Prize 2010 in Universitas Negeri Yogyakarta on May 29, 2010

[29] Sukirno. 2012. "Model Buku Ajar Bahasa Indonesia Berbasis Pendekatan Kuantum Sebagai Upaya Peningkatan Mutu Pembelajaran Bahasa Indonesia.” International Seminar on Scientific Meeting of Indonesian Language and Literature (PIBSI) XXXIV at Jenderal Soedirman University, Purwokerto.

[30] Sukirno. 2013. "Model Buku Ajar Sastra Berbasis Pendekatan Kuantum Sebagai Upaya Peningkatan Mutu Pembelajaran Sastra." Meeting of the Association of Indonesian Language and Literature Educators in Southeast Asia in 2013 at the State University of Jakarta.

[31] Sukirno. Belajar Cepat Menulis Kreatif Berbasis Kuantum. Yogyakarta: Pustaka Pelajar. (2016).

[32] Temple, C., Ruth, N, and Nancy, B. The Beginning of Writing. Boston: Allyn and Bacon, Inc. (1988).

[33] Tompkins, G.E. Teaching Writing: Balancing Process and Producct. New York: Macmillan College Publishing Company. (1994).

[34] Waluyo, Herman J. Drama Teori dan Pengajarannya. Yogyakarta: Hanindita Graha Widia. (2003).

[35] Waluyo, Herman J. Pengkajian dan Apresiasi Puisi. Salatiga: Widyasari. (2010). 